\title{
Economic and Infrastructural Potential of Water Transport in Siberia: Historical Experience and Modern Perspectives
}

\author{
Ilya A. Ageev ${ }^{1,2}$, Vasiliy P. Zinovyev ${ }^{3}$, Maria V. Netesova ${ }^{1}$, Vera V. Ageeva ${ }^{1}$ \& Maria S. Mironova ${ }^{1}$ \\ ${ }^{1}$ Tomsk Polytechnic University, Tomsk, Russian Federation \\ ${ }^{2}$ Tomsk State University of Control Systems and Radioelectronics, Tomsk, Russian Federation \\ ${ }^{3}$ Tomsk State University, Tomsk, Russian Federation \\ Correspondence: Ilya A. Ageev, Tomsk Polytechnic University, Lenina St. 30, Tomsk 634050, the Russian \\ Federation. Tel: 7-923-419-6545. E-mail: agilalex@mail.ru
}

Received: March 15, 2015

doi:10.5539/mas.v9n9p194
Accepted: March 30, 2015 Online Published: August 30, 2015

URL: http://dx.doi.org/10.5539/mas.v9n9p194

\begin{abstract}
Siberian transport corridors, especially river systems, provide transit freight traffic from Asia to Europe from the 18th century. Even in the 19th century, a unique geographical position of Russia contributed to the organization of different projects concerning transcontinental logistic corridor linking the Siberian rivers and their canals. The article presents a comparative analysis of the conditions for ensuring transit traffic along the Siberian rivers in the late 19th century. The example is the construction of the Ob-Yenisei Canal in the current economic situation in Russia. The author attempts to answer the question whether the reasons that put river transport in the "high-risk group" are systemic, historical, or they are the consequence of wrong management at the end of the 20 th century. The purpose of the article is to determine the level of solutions or solvability of the problems that hindered the development of water transport in the late 19th - early 20th century. In addition, the authors are trying to evaluate the competitiveness of river transport in the modern conditions of increasing pressures on Siberian transport infrastructure. The paper identified three clusters of the systemic problems of Siberian water transport - design-technological, organizational and natural-geographic. The results have shown that the solution of technological and management issues, as well as lower costs of operation of water transport did not lead to an increase in the volume of traffic freights along the Siberian rivers. Economic, natural and geographical factors became the most important for the solution of technical problems.
\end{abstract}

Keywords: inland water transport, international consignments, shipping logistics, navigable waterway, the Ob-Yenisei Canal, Siberia, world trade

\section{Introduction}

\subsection{Introduce the Problem}

Modern conditions of world trade, especially long distances between the places of goods production and consumption require reducing logistics expenses. The geographical position of Russia allows using the transport infrastructure of Siberia, especially inland waterway transport, as a trade corridor between Europe and Asia to lower expenses. Ever since the economic development of Siberia, inland waterway transport has been one of the most important factors in the economic development of the region.

Toward this end, proposals for the organization of a large-scale water transport system in Siberia via the construction of several navigable canals were expressed over the last two centuries by scientists, journalists, merchants and managers. The only practical and, unfortunately, unsuccessful realization of these projects was the Ob-Yenisei Canal, built in 1880-90s. The construction and operating experience of the Ob-Yenisei Canal showed a wide range of negative factors slowed the development of river transport at the end of the 19th century in the conditions of the industrial revolution termination. Among the reasons for the failure of this infrastructure project were inadequate budget; hurried exploration and design that entailed errors and inaccuracies in draft limitations and the Canal discharge time curve; and insufficient attention to the integration of the Ob-Yenisei Canal in the overall transport system of Siberia. The poor quality of building materials (overusing of wood, the deficiency of stone and concrete) and lack of equipment prevented the adapting of the project construction under the growing needs of river transport. 
In Soviet times, river transport of Siberia received considerable attention. In 1920s river transport provided the bread supply to European Russia, transit and transhipment wood and graphite onto sea-going ships. Due to the first metallic ships, navigation in the Upper Yenisei and in Mongolia was developed. Rivers were the only transport available to the sparsely populated and remote areas (Northeast Siberia and Russian Far East) and worked in the conditions of industrialization. During the Second World War Siberian river fleet provided military cargo transportation. In the second half of the 20th century shipping covered all large Siberian rivers. Soviet Government funded the reconstruction of ship repair facilities and the mechanization of cargo handling operation on the Irtysh. Area of activities of East Siberian steamship lines included wood transportation within Siberia, freight transit from Krasnoyarsk to Dudinka for Norilsk Mining and Metallurgical Combine's needs, goods traffic connected with gold- and diamond-mining industry in Yakutia. In 1950s significant for their time harbours (Osetrovskiy, Novosibirsk, Khabarovsk, Krasnoyarsk) were put into operation. Increase of East Siberian river traffic was the result of oilfield development and freight traffic to regions of the Far North. Consequently, the idea of restoring of the Ob-Yenisei Canal was repeatedly actualized. The Soviet Union collapsed and shipping industry was stricken with a deep crisis because of the termination of government subsidies.

At the beginning of the 21 st century, Siberian water transport recovered somewhat. Total freight grew and researchers actualized attempts to attract public funding to scientific development and design integration schemes of Siberian river transport to sea and rail (Zachesov \& Ragulin, 2012; Ragulin, 2012; Pustoshnyi, 2013). Nevertheless, modern river transport in Siberia, like transport of megacities, with its great social importance and potential infrastructure, does not bring substantial profits to owner; on the contrary, usually it is a losing endeavor. The search for an answer to the question: "Are the projects of Trans-Siberian water communication suggested by modern Russian researchers realistic?" can be facilitated by the study of historic reasons for a high financial risks of Siberian river transport. Have the problems which led to the failure of the Ob-Yenisei Canal been solved or they are the systematic problems of Siberian water transport? Is it really possible to make this project successful if to take into account all the mistakes?

\subsection{Objectives}

The purpose of the article is to determine whether solutions exist to the problems that have hindered the development of water transport in Siberia since the late 19th - early 20th century. The research is focused on water transport in Siberia at the end of the 19th - the beginning of the 21st centuries. The authors attempt to define the evolution of constraints of water transport development in the late 19th - early 21th century and evaluate the competitiveness of river transport in modern conditions of high railway fares and inadequate quality of Siberian transport infrastructure.

\subsection{Explore Importance of the Problem}

The study of high expenses and low efficiency of Siberian river transport was traditionally provided by economic methods, without understanding of the historical background of the problem. The Ob-Yenisei Canal is used as the main object to monitor the connecting river canal - an illustrative example for failures of governmental attempts to improve the water transport infrastructure in Western Siberia. The history of the construction and operation of the Ob-Yenisei Canal shows the majority of conflicts that prevented the development of such objects in the 20th century. The obtained results let us determine the prospects for the development of the Siberian water transport in the future. The novelty of the research results is determined by the introduction of a new scientific historical sources - the designing and reporting instruments of the Railway Ministry and its subordinate departments of the late 19th - early 20th century (the Russian State Historical Archive [RGIA]); news reports and journalistic materials devoted to the Ob-Yenisei Canal, published in "Siberian Bulletin" and "Eastern Review" (digitized materials of Scientific Library of Tomsk State University) in the end of the 19th century.

\section{Literature Review}

The study of the problems of the sea and river transport development occupies an important place in modern scientific field and is carried out using a variety of research strategies at the intersection of social, economic and human sciences. The main research focus is water transport cost reduction, enhancement and simplification of procedures. An impressive body of research provides an analysis of certain aspects of the intermodal (Southworth \& Peterson, 2000; Priemus, 1999) and container (Seok Min Lim, 1998; Alekhin, 1999) shipments. Significant experience in socio-economic study water transport systems of Russia gained in the modern world economic geography, primarily within the Arctic Research (Brigham, 2001; Sawhill \& Ragner, 2002; Stephenson, Brigham \& Smith, 2014; Schwarz, 2006; Josephson, 2008, 2011) and the Asian part of Russia (Bandman, Malov, 2001, 2002). 
A special place among Russian economic-geographical research is given to river transport efficiency in a market economy conditions. For instance, V.A. Vinichenko $(2007,2009)$ and V.P. Zachesov $(2006)$ prove the priority of water transport in the development of difficult access and sparcely populated areas. S.N. Maslennikov (2008) indicates that the pace of transport infrastructure development should outpace the development of Russian economy whereas I.G. Futik (2009) and Yu.A. Krupnov (2008) state resource and institutional constraints, which could affect Siberian river transport. In the assessment study of Russian oil shipment I.D. Maksimov (2013) concluded that the main hindrance to traffic growth is low sluicing cantilevering of dams and canals. However, the study of Russian water transport system using the methodology of history, geography and economics was not provided.

Interesting results in the study of water transport have been achieved in specific historical and applied research at the regional level. Addressing to the historical and contemporary practices of solving problems of transport maintenance of Siberia, the authors were seeking to identify regional specific of interaction between public authorities and society (Safronov, 2010; Shaherov, 2011; Bolshakov, 2007; Ageev \& Ageeva, 2015), justify the need for large-scale development of Siberia transport (Nevostrueva, 2013; Shilovskiy, 2008). S.A. Safronov (2010) reviewed the activities of a special commission established in Irkutsk in 1906 to improve transport service for the purposes of Stolypins agrarian reform. Initiative proposals of this commission included the reconstruction of the Ob-Yenisei Canal. V.N. Bolshakov (2007) described another attempt to recover an inactive Canal - governmental discussions and expeditions aimed at restoring the Ob-Yenisei Canal in 1912. According to M.V. Shilovskiy (2008), in the late 19th - early 20th century Russian government tried to make good the deficiency of Siberian transport infrastructure by means of different projects, for instance, the expansion of the Moscow-Siberian Tract; goods delivery to Siberian towns by the Kara Sea. The research of prospects for the establishment of trans-Asian logistics corridors have been forced into a separate line (Lamin \& Plenkin, 1999). A large array of studies with varying degrees of chronological coverage carried out in relation to the Ural, Siberian and Far East regions.

In the research discourse the ambitious projects of including the Siberian water transport system in the world water system and a statement of unavailability of water transport in Siberia to do similar functions in a changing economic environment coexist. In recent studies of the Russian water transport, the historical experience of the organization and operation of large-scale water facilities and transport infrastructure has not been practically involved. However, it would let identify the historically conditioned risk factors of the modern water transport. Analysis of the degree of correlation of historical and modern problems of Siberian water transport forms a research gap, which is going to be filled by the current study.

\section{Teoretical Framewoks and Historical Sources}

Along with the general scientific principles of the system and historicism, the authors rely on traditional tools of historical science - historical-genetic, comparative, typological, problem-chronological methods. This study employs the special methods that are included in the theory of post-industrial society and the disciplinary-genetic approach of Teun A. van Dijk. The improvement of railway in Siberia in the second half of the 19th century fit into the context of the transition of the region from pre-industrial to an industrial society therefore the attraction of the modernization theory does not lose its relevance. The Ob-Yenisei Canal demonstrates the duality of social and economic processes, for instance, attempts to meet the new industrial tasks using traditional, pre-industrial tools and techniques.

Sources on the history of the Ob-Yenisei Canal include:

1) Record management documents of the Ministry of Railways of the Russian Empire and its subordinate departments, stored in the Russian State Historical Archive (RGIA), St. Petersburg. In particular, the official documents of the financial, technical and administrative aspects of the construction and operation of the Canal.

2) The collection of printed notes - Special Fund of RGIA containing presentation and reporting materials about design and building of the Canal for State Council.

3) The complex of the printed materials of Siberian newspapers at the end of the 19th century: "Siberian Bulletin" (Tomsk, from 1885 to 1902) and "Eastern Review" (Irkutsk, from 1882 to 1906).

4) Technical Reports of engineers-auditors of the Ob-Yenisei Canal issued in the form of the brochures and stored in the National Library of Russia (RGIA, St. Petersburg).

The documents describing the strategy for the development of transport system of Russia as a whole and river transport in particular, posted on the website of the Ministry of Transport of the Russian Federation became the sources of the current state of transport. Working with archival documents (reports of engineers working on the 
Ob-Yenisei Canal, auditor reports of government departments, journalistic articles) authors are basing on the method of discourse analysis, which allows to determine the "politics" of the text (author's conscious goal-setting), narrative and not narrative types of presentation in the text, inevitably conflicting figures of logic and rhetoric, the ways of structure the content and means of author's expression.

\section{Results and Discussion}

\subsection{The Typology of Reasons for the Failure of the Ob-Yenisei Canal as an Infrastructure Project}

The Ob-Yenisei Canal is located at the boundary of Tomsk and Krasnoyarsk regions (coordinates: $59^{\circ} 12^{\prime} \mathrm{N} 88^{\circ}$ 3'E). The Canal connects confluents of the $\mathrm{Ob}$ and the Yenisei placed close together (Figure 1).

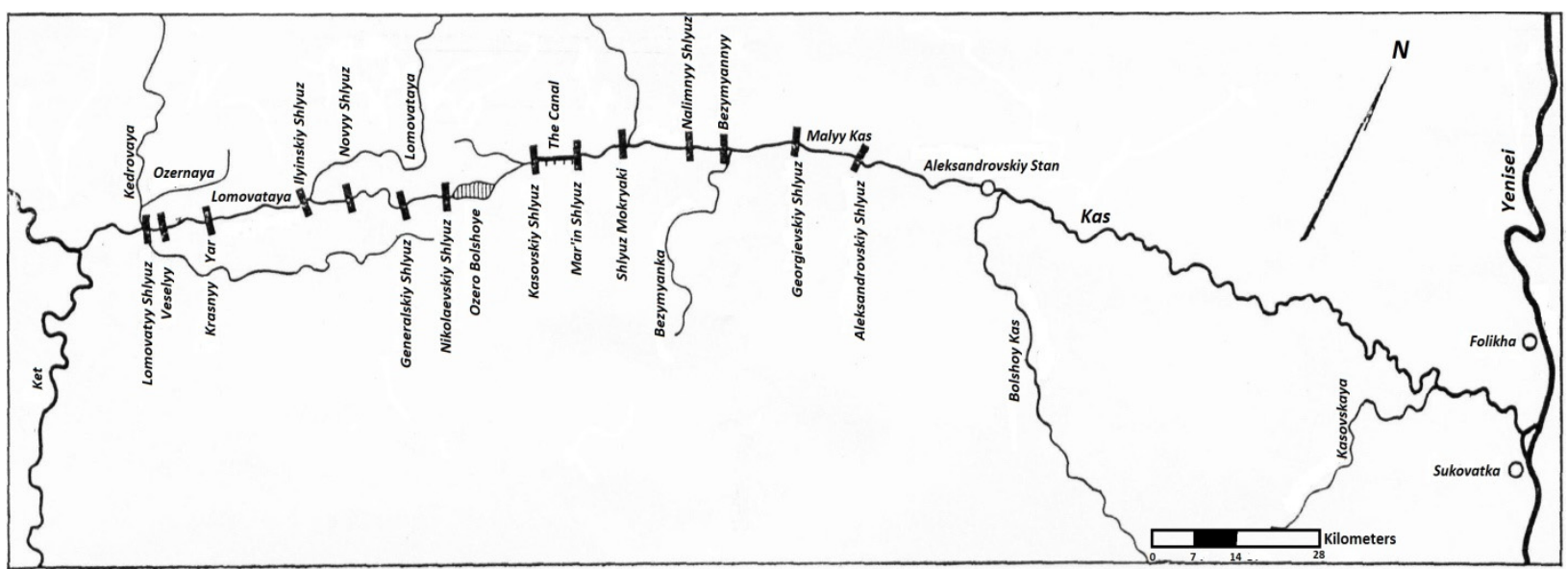

Figure 1. The Ob-Yenisei Canal from the Ket to the Yenisei

This is the only artificial navigable canal in the Asian part of Russia. A boat can float down the Ob-Yenisei Canal only in spring. Proposals to build a canal from the $\mathrm{Ob}$ to the Yenisei occurred a few times in the 19th century. Yeniseisk merchant P.E. Funtusov found out the location for the Canal construction in 1872. Ministry of communication lines organized two expeditions to the drainage divide of the $\mathrm{Ob}$ and the Yenisei. In 1875, a conductor of the expedition was an engineer A.K. Sidensner. In 1877, an engineer B.A. Aminov conducted the second expedition. Both expeditions proved the possibility of the Canal construction. In 1881, Bjork Aminov prepared a project of the Ob-Yenisei Canal in two variants - maximum (for ships of 80 tons displacement) and minimum (less costly design for ships of 8 tons) versions. Ministry of communication lines approved the second, proof-of-concept project and promised to finance additionally an upgrade in case of the canal efficiency. The Canal was built from 1884 to 1886 . Floodgates and dams on the rivers connected with the Canal were built from 1887 to 1898 (Figure 2).

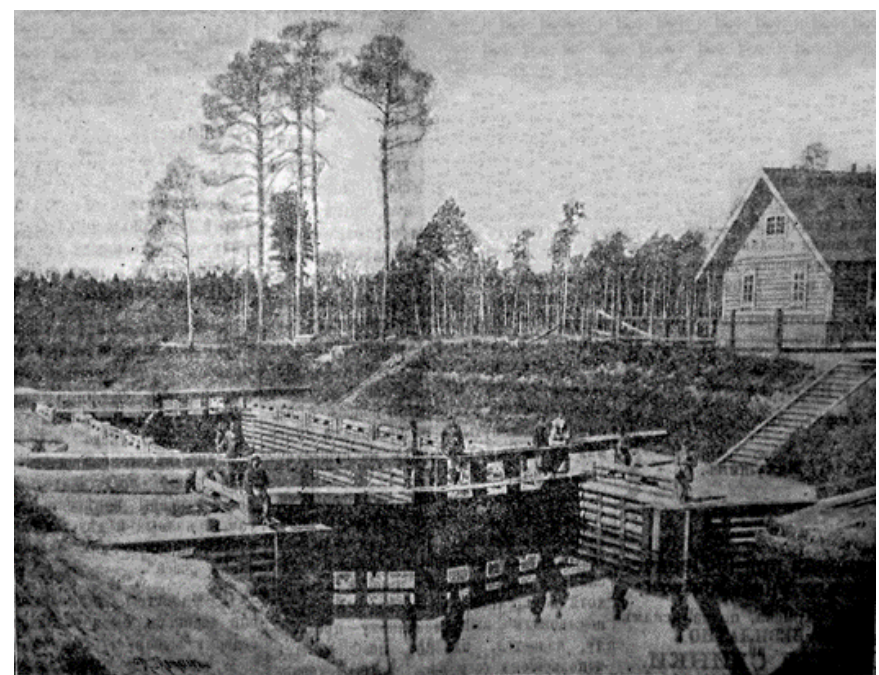

Figure 2. The Ob-Yenisei Canal. A photograph from the newspaper “Tomskiy Listok", March 1, 1897, No. 48, p. 
Official operation of the Ob-Yenisei Canal lasted from 1888 to 1921. However, cargo traffic was not more than 1600 tons within a navigation season. In 1905, the Canal managed to transit 8000 tons of cargo in consequence of the Russo-Japanese war. Reconstruction projects were considered in 1895, 1904-1905, 1909-1915.

According to the results of sources studying three clusters of factors and conditions have been identified. They hindered the Ob-Yenisei Canal from the development into a full-fledged infrastructure at the end of the 19th century.

1. Reasons related to the characteristics and quality of the project, the circumstances of its adoption, as well as the level of technology used in the construction:

- Errors in determining the depth and width of the river, made during the reconnaissance and in the preparation of the preliminary draft (RGIA, Fond 180, Inventory 1, Unit 8, Sheet 131; Siberian bulletin, 1890, October 3, 1891, October 16);

- Misconceptions about the cost of the project and service tariffs (RGIA, F. 180, Inv. 1, U. 8, Sh. 81);

- Wrong decision to construct the Canal based on the "cheapening" project, developed by engineers as a test case, without a proper explain (RGIA, F. 174, Inv. 1, U. 4473, Sh. 23, 25-33, 37-40, 45);

- The incongruous size of the gateway passes to the size of ships that were going on the $\mathrm{Ob}$ and Yenisei river basins, and the lack of funds for their expansion (Siberian newspaper, 1885, December 1);

- The low level of water in locks and their unsatisfactory filling speed with the natural way (RGIA, F. 180, Inv. 1, U. 155, Sh. 125; Siberian bulletin, 1890, September 26, October 3).

2. Problems related to the management of resources, personnel and finance:

- Difficulties in labor force providing (RGIA, F. 446, Inv. 28, U. 8, Sh. 106; RGIA, F. 174, Inv. 1, U. 8497, Sh. 30; Zhitkov, 1887, p.13);

- The deficiency of public funding and the lack of mechanisms to attract private capital (RGIA, F. 174, Inv. 1, U. 1524, Sh. 1-5, 40);

- Expensive food, building materials and labor in the absence of adjustments to the overall financing of the project, which resulted in a reduction of funds remaining on the actual needs of the construction of the Canal (Siberian bulletin, 1885, December 12);

- High costs of providing labor and living conditions for workers: delivery and storage of food in the absence of refrigerators, distraction workers on non-production needs, for example, to help stranded ships supplying construction (RGIA, F. 174, Inv. 2, U. 2072, Sh. 1; Siberian newspaper, 1885, December 1; Siberian bulletin, 1890, September 26, October 24);

- Harsh environment of the Siberian North, increased morbidity and mortality among workers from scurvy, an abundance of midges (Siberian bulletin, 1886, July 13, 1890, October 24; Zhitkov, 1887, p. 13; Siberian newspaper, 1885, December 1);

- High expenses for construction and operation of the Canal due to unreasonable broad usage of manual labor (Ageev, 2012, pp. 67-68).

3. Socio-economic and natural-geographical factors influencing the Canal operation and freight acquisition:

- Limited navigation on the Angara river (RGIA, F. 180, Inv. 1, U. 11; Annual Report of Yenisei governor, 1897; Annual Report of Yenisei governor, 1895; About the establishing);

- Short-term navigation (Siberian bulletin, 1890, October 24, 1892, September 26; Zhitkov, 1887, p. 15);

- Rivalry between the Canal and the Trans-Siberian Railway (Eastern Review, 1891, November 17);

- The lack of resident population in the watershed of $\mathrm{Ob}$ and Yenisei for the potential use of the Canal for the local shipping (Ageev, 2012, p.82);

- The deficiency of goods which river transportation is economically advantageous (Stanislavskiy, 1895);

- Logistic disadvantage of the position of the Canal towards the commercial and industrial centers of Western Siberia (Siberian bulletin, 1896, October 4);

- Narrow impassable places - "bottleneck" - on the way to the Ob-Yenisei Canal and in the headwaters (RGIA, F. 180, Inv. 1, U. 155, Sh. 121-122).

- 


\subsection{Negative Factors Affecting the Operation of Modern Inland Waterways}

In modern conditions in order to assess the degree of solvability or solutions of the problems of the Siberian water transport of the late 19th - early 20th centuries, which have been identified by the example of the Ob-Yenisei Canal, we should pay attention to the current state of water transport and the reasons hindering its development. According to the "Strategy of inland water transport development in the Russian Federation for the period up to 2030", the main reason for the low efficiency of river transportation is the destruction of traditional transport schemes of goods delivery by river transport, including intermodal traffic in the 1990s (Strategy, 2013). The second negative factor is the reduced competitiveness of river traffic due to the deterioration of inland waterway infrastructure, increasing the empty runs, rising fuel prices, the outflow of qualified personnel from the industry. The high wear of river transport fleet and the low level of shipbuilding thwart progress of inland navigation too. Land transport modes as well as pipelines develop more dynamically than water transport. Infrastructure constraints include the exhaustion of carrying capacity of some locks and hydropowers. Cost of vessel construction is high, while profitability of the shipping business is low. Furthermore, organizational and legal rules governing water transport are imperfect.

I.G. Futik (2009) held the systematization of the risks of modern Russian enterprises of water transport, dividing them into three groups of external risks (legislative and political; financial and economic; natural) and four groups of internal factors (organizational and administrative; contractual; resource; insurance). This complex classification coincides with the systemic problems of the Siberian water transport, which is the focus of our study in three clusters: 1) technological and design, 2) organizational and management, 3) natural-geographic and logistical risks.

Based on the analysis of historical sources (archival materials on the history of the Ob-Yenisei Canal) and current data on the state of water transport (Strategy, 2013), we compared the influence of the main factors hindering the operation of the Siberian water transport and constraining its modern development at the end of the 19 th century.

\subsection{The Level of Solutions of Design and Technological Problems of Siberian Water Infrastructure in Modern Conditions}

Among three clusters of identified system problems of the Siberian water transport solutions of design and technological problems at the end of the 19th century is the most obvious. The most objective problem of this cluster was insufficient water level in locks. It was technically solved at the beginning of the 20th century, even before the decommissioning of the Canal. For instance, one of the solutions of the problem was described in the 1900 s by an engineer N.P. Puzyrevsky (1907). The rest of the technological difficulties, related to the low quality of the construction work and the shortsightedness of the project construction, the lack of it in reserve for increasing the load capacity and size of vessels. In the 21th century, transport infrastructure projects undergo compulsory state examination, even if the evidence of the project is not in doubt (Port Bronka, 2014). At the end of the 19th century, the State Council got only a project of the Canal construction. Engineers and Yenisei merchants lowered the cost of the planned construction work at the end of the 19th century. Therefore, they managed to convince the authorities that the first phase of the construction did not require a large investment, and bring the money to expand. Nowadays all the infrastructure projects cannot be launched without modifications during the construction phase: it increases its cost, but allows maintaining the relevance for the economy. Mistakes and miscalculations, as well as difficulties in the water transport, identified in the 19th-20th centuries, with the development of technologies and the improvement of management practices have lost the sharpness and urgency. With some reservations, design and technological issues that are included in the first cluster can be considered as resolved.

\subsection{The Level of Solutions of Management Problems of the Siberian Water Transport in Modern Conditions}

Problems included in this cluster were largely unique for Russian infrastructure projects in the late 19th century. During the construction of the Ob-Yenisei Canal, Russian engineers encountered them for the first time in their practice. The Ob-Yenisei Canal as a large-scale and industrial inherently structure created without the use of electricity and steam engines, in a considerable distance from residential areas that led to a shortage the necessary of resources and high costs for their transportation from Tomsk. Despite the seeming solution to the problems of the cluster, the costs associated with the management and supply of construction work has not been reduced. Indeed, in modern conditions glaciers, cellars and salting meat are not required for food preservation. Availability of fresh products and medical advances reduce the risk of scurvy and other diseases. Many jobs in the construction have become mechanized; use of aircraft and motor vehicles accelerated procurement and delivery of workers. Means of communication and information save time and optimize the costs of resource 
management. The sources of financing, the government no longer makes unreasonable rates on their own strength: developed mechanisms for attracting private money, while maintaining state control.

However, a detailed analysis reveals that there was no reduction but it was the redistribution of expenses in the management and supply of construction work. Logistics innovations have accelerated and facilitated the delivery of workers and necessary things, but the cost of transport services increased. Air transport in the northern areas is 5 (Nordtrans, 2014) to 20 (Transport company PEC, 2014) times more expensive than land transportation. The labor force also has not become cheap resource: in northern Siberia large industrial facilities are still served in shifts, since the permanent population in the area over the past 130 years has not changed. In addition, in accordance with the modern Russian labor legislation rates of pay are higher in areas equivalent to the Far North. The reducing of manual labor led to the emergence of new items of expenditure: energy resources. The increasing of energy expenses is the leading problem of modern Russian economy. In the difficult terrain energy costs is further increased.

To a new kind of costs the growth in maintenance work can be attributed while ensuring traffic inevitably follows the growth of traffic on the waterway, an increase of tonnage and dimensions of barges. The Ob-Yenisei Canal was shown as an object, cheap to maintain, as it involves the construction of only two gateways. The project was approved by the State Council in 1881 . However, by the beginning of the 20th century the engineer Zhbikovsky (1903), analyzed the cost and the amount of maintenance work on 14 additionalyl built locks, pointed to the loss-making operation of the Ob-Yenisei Canal even under the ideal flow of goods because of the high costs of maintenance of hydro. Nowadays the complex of maintenance work has become more intricate and spread beyond the artificial waterworks. Without proper maintenance the capacity of ports and gateways is reduced, and complex areas in the upper reaches of the rivers are excluded from shipping (Krupnov, 2008, p.45-60). The modern complex of navigation service includes setting marks, ensuring guaranteed dimensions, bottomcleaners, shore protection, deepening of canals, straightening the bottom, regulation of river flows and other works (Novoseliev et al., 2006, p. 55-60).

Thus, the development of technologies and management let eliminate a number of organizational and administrative costs, but the rest of them (transportation and labor) and the newly emerged (energy needs and service) have become more costly. There was no a reduction in this cluster, but the redistribution of costs. Based on the conclusions of the second cluster the prospect of successful development of the Ob-Yenisei Canal through savings in construction and low operating rates becomes doubtful.

\subsection{Analysis of the Natural Geographic and Logistical Risks of Siberian Water Transport}

Nature of Siberia cannot be considered conquered up to the present time: climate and geographic position give objective obstacles for the work and the development of infrastructure. The underestimation of many natural and geographical factors did not allow to take an objective decision on whether to start construction of the Ob-Yenisei Canal at the end of the 19th century or not. Was it possible to adapt Siberian waterway infrastructure in combination with natural conditions over the past 130 years? Even before the completion of the Ob-Yenisei Canal, the first systemic problem for the development of freight traffic in the direction of Eastern Siberia became the Angara River and its rapids. In the 1870s, the cost of removing threshold was estimated at 2 million of silver rubles. However, nobody had such money those times. Famous Siberian merchant A.M. Sibiryakov wanted to submit the navigation on the Angara River using chain boat navigation. In 1885, he received a monopoly on navigation on the river for five years. Nevertheless, after failing to overcome Padunskiy threshold, he turned the company (Raspopina, 2004).

Later, in the 20th century the Angara River hydroelectric system was built, which hid most of the Angara rapids, with expanded areas of continuous navigation, but a single waterway on the Angara still did not emerge. The building of shipping locks, allowing overcoming the dam, has been postponed until the end of Nizhneangarsk stage, which is currently only designed (Boguchanskaya, 2009). The main problem is the closed river basins, which cannot permit to extend the influence of the freight loads: the river fleet becomes a hostage to the river on which it runs. In the European part of Russia, this shortcoming was resolved by creating a united deep water system, through the construction of navigation canals in the years of Stalin's industrialization. However, the system of the largest Siberian rivers was not connected with important seaports of the Black Russian Sea, Japanese, Baltic and Barents seas, although the first proposals to eliminate the restraint of the Siberian rivers came in the 19th century. The expanding of boundaries of the river transport influence of networks is an important task of modern river transport specialists. The possibility to construct navigation canals through the mountains gives sense to the alternative schemes. For instance, N. Efremov notes the low profitability of modern Russian river transport, non-competitive compared with road transport, and proposes to create a system of 
multimodal transport, where vehicles and railways receive congestion reduction, and the restraint of water transport is eliminated (Efremov, Kostrov, Etin \& Mitroshin, 2008). Concerning Siberian rivers this proposal would relieve some transport inaccessibility of waterways in Siberia.

The second negative reason of this claster, which influenced the work of the Ob-Yenisei Canal, was the short-term navigation. At the end of the 19th century navigation along the Siberian rivers was possible only for 4-5 months a year, and this situation has not totally changed nowadays (Krupnov, 2008, p. 16). The short terms of navigation and the inability to affect the time they begin and end reduce the possibility for river transportation in modern conditions than it was in the 19th century. Different pace of life, the acceleration of the business cycle and tougher sanctions for the failure of the supply contracts, as well as the absence of special credit terms for shipping companies make it unacceptable for the transport of small and medium-size Russian businesses.

Competition with the railway construction in the modern notion of the Ob-Yenisei Canal was the main reason of failure of this waterway. Nowadays the competition with different modes of transport has a negative impact to the river fleet but it does not usually lead to destabilization due to the natural distribution of goods. I.D. Maksimov has analyzed the state of petroleum products transportation by river routes in European Russia and came to the conclusion that the low bandwidth of gateways increases the trip time, which equates to a demmurage (Maksimov, 2013). In addition, the high concentration of communications crossing the rivers, inevitably reduces the rate of water traffic. The construction of bridges and dams gives disadvantages to the water transport, since most of bridges and dams all forced to slow down and take additional maneuvers.

The lack of population in the region of the Ob-Yenisei Canal is the problem, which has not been solved over the last 130 years. The population of Siberia as a whole has increased several times, but mainly due to the southern regions. The rest of the territory of Siberia was successfully settled only in the presence of external stimulation: high wages, favorable conditions for retirement, housing. With the elimination of such preferential treatment the outflow of the population was observed. Ob and Yenisei watershed is rich in oil, but in Soviet times its development was delayed. It made imossible to attract permanent population, so there was no necessity in local water traffic, which would maintain the infrastructure in working condition. The need in the permanent population for the appropriate work of Siberian river transportation is mentioned by E.A. Vinichenko, analyzing the state of the infrastructure in terms of the Siberian oil pipeline "Eastern Siberia-Pacific Ocean" (Vinichenko, 2011).

The problem of providing waterways with freights is not solved. The range of goods, which are beneficial to convey by the means of water transport, now is as limited as in the 19th century, and it is reduced continuesly. All types of freight transport by the means of river are beneficial only in the implementation of the "northern delivery", and the rest of the work of the Siberian river transport obeys the formula "a massive and cheap goods not requiring urgent delivery". In the 19th century salt, coal, metal and grain were under this definition. Modern composition is much smaller: non-metallic building materials - gravel, sand and gravel (67\%), oil and oil products $(10 \%)$, wood $(5.5 \%)$ (Krupnov, 2008, p. 9). Other goods cannot provide water transportation beneficially. Caravan of six barges can carry the load equivalented to 1000 open-top wagons. In conjunction with a low speed of water transport, the competitive advantages disappear completely. Shipping companies have to deal with the transport of those goods that cannot physically be placed on railway platforms, such as generators for hydroelectric power plants. To provide the Siberian river transport with freights flexibilities in tariff and shipping and long-term cooperation with the largest companies are required.

The well-established and stable supply of goods by means of water transport cannot have significant role in the Siberian river transport, if there is no market and real demand orientation, though. Contemporaries the Ob-Yenisei Canal called it as a "desk work". Numerous projects concerning the organization of Trans-Asian water route along the rivers based on idea that "it would be cheaper", turned out to be illusions. Theoretical calculations of the "economy of the Treasury", which Russian economists and engineers in the 19th century were talking about, does not work in the present situation. The mechanistic approach to the design of transport communications is typical for modern Russian practice of infrastructure management. They are expressed in the attempts to artificially redirect traffic flows along paths, which viability has not been proved in practice. However, it is really impossible to make business use untested area of water transport. Shippers from the eastern Asia use the functioning maritime transport effectively (Structure, 2013), and there are no real reasons to think that water transport can help to reduce the expenses. Consequently, the revealed reasons of the third cluster are largely not resolved and now have the same, and sometimes even more negative impact on the development of shipping than it was in the 19th century. 


\section{Conclusion}

The system problems of the Siberian water transport, which origins go back to the 19th century, form three conventional clusters: design-technological, organizational-administrative and natural-geographic issues. Key reasons for the failure of construction and operation of the Ob-Yenisei Canal at the end of the 19th century were not associated with the prematurity, lack of money or the low level of hydraulic engineering, but with the non-economic methods of prospects estimating of an infrastructure project. The most of the reasons preventing the development of the Ob-Yenisei Canal are overcome. However, the social-economic reasons are still actual. Technological and managing problems do not let Siberian water transport come to the highest competitive level. The reduction of the expenses of water transport exploitation did not lead to an increase in the volume of traffic on the Siberian rivers. With the solution of technical problems, the natural geographic and logistical risks have come to the fore. River transport in Siberia can be profitable and competitive only under the certain conditions. They are the continuous monitoring of changes in freight traffic, modern adjustment of logistic schemes and maintenance of infrastructure at the appropriate level to the needs of the economy.

\section{Acknowledgments}

The research reported in this article was supported by the Strategic Programme on National Research Tomsk Polytechnic University Competitiveness Enhancement in the Group of Top Level World Research and Academic Institutions. The present work was partially supported by RFBR, in the framework of the project "Trends of the modern world Russian studies: research paradigms, discourse genres and the use of ICT-resources as a modernization concept of historical science and education" (No. 12-06-33018 mol-a-ved).

\section{References}

About the establishing of Western Siberian Department of navigable waterways. Collection of printed proceedings, 102. The Russian State Historical Archive (RGIA).

Ageev, I. A. (2012). History of Ob-Yenissei Canal (Unpublished doctoral dissertation). Tomsk State University, Tomsk, the Russian Federation.

Ageev, I. A., \& Ageeva, V. V. (2015). Urban lifestyle as an element of consumption ideal and economic wellbeing: meaning-changing transformation from Soviet period to modernity. Procedia - Social and Behavioral Sciences, 166, 24-29. http://dx.doi.org/10.1016/j.sbspro.2014.12.477

Alekhin, A. V. (1999). Geographical issues of cargo container application at the sea transport. Vestnik Moskovskogo Universiteta, Seriya 5: Geografiya, 1, 60-64.

Annual Report of Yenisei Governor for 1895 year. Collection of printed proceedings, 2825. The Russian State Historical Archive (RGIA).

Annual Report of Yenisei Governor for 1897 year. Collection of printed proceedings, 2825. The Russian State Historical Archive (RGIA).

Bandman, M. K., \& Malov, Yu. V. (2001). Transport complex of Russian Asia: Strengthening of economic safety. Izvestiya Akademii Nauk, Seriya Geograficheskaya, 2, $12-24$.

Bandman, M., \& Malov, Yu. (2002). New transport system formation as an entrance to the world market for Siberian regions. Global Economic Review, 31(4), 39-55.

Boguchanskaya Hydro Power Plant. (2009). Preliminary social and economical evaluation as part of bank feasibility study. Retrieved from http://www.boges.ru/eko/note.pdf

Bolshakov, V. N. (2007). About the history of the Ob-Yenisei Canal. Tomsk State University Journal, 295 , 105-110.

Brigham, L. W. (2001). The northern sea route, 1999-2000. Polar Record, 37(203), 329-336.

Eastern Review. (1891, November 17). Digitized materials of Scientific Library of Tomsk State University. Retrieved from http://sun.tsu.ru/mminfo/000349167/index.html

Efremov, N. A., Kostrov, V. N., Etin, V. L., \& Mitroshin, S. G. (2008). River transport development in the 21 th century - new technologies. Bulletin of Volga region transport, 4, 56-62.

Futik, I. G. (2009). Economic analysis of losses and resources risks concerning with the economic activity of water transport enterprises in Siberia (Unpublished author's abstract of a doctoral dissertation). Siberian Transport University, Novosibirsk, the Russian Federation.

Josephson, P. (2008). Russian roads and railroads. Journal of Transport History, 29(2), 237-239. 
Josephson, P. (2011). Technology and the conquest of the Soviet Arctic. Russian Review, 70(3), 419-439.

Krupnov, Yu. A. (2008). Russian waterways and Eurasian transport infrastructure. Moscow.

Lamin, V. A., \& Plenkin, V. Yu. (1999). Global track: the development of the transport system in the East of the country. Ural Branch of the Russian Academy of Sciences.

Maksimov, I. D. (2013). Status and prospects analysis of river transport infrastructure development (petroleum transportation) in European Russia. Infrastructural sectors of economy: development problems and prospects, $1,185-190$.

Maslennikov, S. N. (2008). State and business partnership as an economical mechanism for the implementation of Siberian inland navigation development strategy. Scientific challenges of Siberian and Far East transport, $1,11-15$.

Nevostrueva, A. F. (2013). Peculiarities of development of information and communication space of the Russian Empire in the period of reforms (second half of XIX-early XX centuries). Middle East Journal of Scientific Research, 17(1), 16-20. http://dx.doi.org/10.5829/idosi.mejsr.2013.17.01.12119

Nordtrans. (2014). Freight Company. Retrieved from http://www.nordtrans.ru/rasstoim.htm

Novoseliev, B. F., Efremov, N. A., Vorontsov, V. M., \& Pospelov V. I. (2006). Inland navigation in Russia. Moscow.

Port Bronka. (2014). Description of the Canal. Retrieved from http://www.port-bronka.ru/descr/opisanie-cin-14/

Priemus, H. (1999). On modes, nodes and networks: Technological and spatial conditions for a breakthrough towards multimodal terminals and networks of freight transport in Europe. Transportation Planning and Technology, 23(2), 83-103.

Pustoshnyi, A. V. (2013). Prospects for high-speed water transport in Russia. Herald of the Russian Academy of Sciences, 83(6), 506-512. http://dx.doi.org/10.1134/S1019331614010043

Puzyrevsky, N. P. (1907). The construction of the navigable infrastructure under unfavourable conditions of climate and meals: description of different ways to solving the problem. St. Petersburg, Department of inland waterways and highways.

Ragulin, I. A. (2012). Siberian inland navigation in transitional period. Scientific challenges of Siberian and Far East transport, 2, 69-73.

Raspopina, A. A. (2004). Development of shipping in the Baikal water basin in the middle of the 19th - the first quarter of the 20th centuries (Unpublished author's abstract of a doctoral dissertation). Irkutsk State University, Irkutsk, the Russian Federation.

Safronov, S. A. (2010). Development of Eastern Siberian inland navigable system in the period of Stolypins agrarian reform (1906-1917). Bulletin of Altai State University, 4(2), 190-197.

Sawhill, S. G., \& Ragner, C. L. (2002). Shipping nuclear cargo via the northern sea route. Polar Record, 38(204), $39-52$.

Schwarz, J. (2006). The Northern Sea route in focus. Proceedings of the International Conference on Offshore Mechanics and Arctic Engineering - OMAE. http://dx.doi.org/10.1115/OMAE2006-92635

Seok, M. L. (1998). Economies of scale in container shipping. Maritime Policy and Management, 25(4), 361-373.

Shaherov, V. P. (2011). Eastern Siberian inland navigation in the 18th - the first half of the 19th centuries. Historical, philosophical, political and legal sciences, cultural studies and art history. Theoretical and Practical Issues, 6(2), 188-192.

Shilovskiy, M. V. (2008). Transport projects of Asian Russia before 1917. Bulletin of Nizhnevartovsk State University, 3, 8-13.

Siberian Bulletin (1885 - 1898). Digitized materials of Scientific Library of Tomsk State University. Retrieved from http://sun.tsu.ru/mminfo/000349027/index.html

Siberian Newspaper (1881-1887). Digitized materials of Scientific Library of Tomsk State University. Retrieved from http://sun.tsu.ru/mminfo/000351029/index.html

Southworth, F., \& Peterson, B. E. (2000). Intermodal and international freight network modeling. Transportation Research Part C: Emerging Technologies, 8(1-6), 147-166. 
Stanislavskiy, A. (1895, September 10-12). How to deal with Ob-Yenissei Canal? Siberian Bulletin.

Stephenson, S. R., Brigham, L. W., \& Smith, L. C. (2014). Marine accessibility along Russia's Northern Sea route. Polar Geography, 37(2), 111-133. http://dx.doi.org/10.1080/1088937X.2013.845859

Strategy of inland water transport development in the Russian Federation for the period up to 2030 (2013). Transport Ministry of the Russian Federation. Retrieved from http://www.mintrans.ru/documents/detail.php?ELEMENT_ID=20607

Structure of global cargo turnover (2013). Volgaprom-expert. Retrieved from http://www.volpromex-ru.1gb.ru/informacija/struktura-mirovogo-gruzoborota.html

Transport company PEC (2014). Freight calculator. Retrieved from http://pecom.ru/ru/

Vinichenko, V. A. (2007). The arrangements of inland navigation efficient use during the construction of the oil-trunk pipeline "Eastern Siberia - the Pacific Ocean". Scientific challenges of Siberian and Far East transport, 2, 29-34.

Vinichenko, V. A. (2009). Optimization of the inland navigation contribution to the construction of the oil-trunk pipeline "Eastern Siberia - the Pacific Ocean". Scientific challenges of Siberian and Far East transport, 2, 114-118.

Vinichenko, V. A. (2011). River transport potential for large economic development projects in Siberian region. (Unpublished author's abstract of a doctoral dissertation). Siberian Transport University, Novosibirsk, the Russian Federation.

Zachesov, V. P. (2006). Economic development of Siberian inland navigation. Transport of the Russian Federation, 5, 17-20.

Zachesov, V. P., \& Ragulin, I. A. (2012). Siberian rivers as a part of the international transport corridors. Scientific challenges of Siberian and Far East transport, 1, 9-13.

Zhbikovsky, S. A. (1903). The Ob-Yenisei Canal and his economic value. Materials for description of Russian rivers and the history of the improvement of its shipping conditions, 2. St. Petersburg, Department of inland waterways and highways.

Zhitkov, S. M. (1887). The Ob-Yenisei Canal (Report was made at the Meeting, October 10, 1886). News-bulletin of the Railway Engineers Meeting, 4(1), 1-15. St. Petersburg.

\section{Copyrights}

Copyright for this article is retained by the author(s), with first publication rights granted to the journal.

This is an open-access article distributed under the terms and conditions of the Creative Commons Attribution license (http://creativecommons.org/licenses/by/3.0/). 